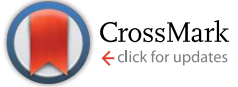

Cite this: RSC Adv., 2017, 7, 15582

Received 23rd January 2017

Accepted 3rd March 2017

DOI: 10.1039/c7ra01038a

rsc.li/rsc-advances

\section{Enantioselective Barbier-type allylation of ketones using allyl halide and indium in water}

\author{
Shuichi Nakamura, ${ }^{\text {ab }}$ Yoshichika Hara, ${ }^{a}$ Takashi Furukawa ${ }^{a}$ and Tsunehisa Hirashita ${ }^{a}$ \\ We disclose herein an efficient enantioselective Barbier-type allylation of ketones using allyl halide and \\ indium metal in water. The reaction was catalysed by chiral bis(imidazoline) to afford homoallylic \\ alcohols having quaternary stereocenters in good yield with moderate to good enantioselectivity. Based \\ on experimental investigation, a possible transition state has been proposed to explain the origin of the \\ asymmetric induction.
}

Optically active tertiary homoallylic alcohols are an important class of synthetic intermediates because they often act as useful chiral building blocks for the synthesis of biologically active compounds. One of the most efficient methods for the synthesis of optically active tertiary homoallylic alcohols would be the catalytic enantioselective allylation of ketones. Although there are many papers on the catalytic enantioselective allylation of aldehydes, catalytic enantioselective allylation of ketones have been far less explored probably due to their low reactivity and the difficulty in enantiofacial discrimination of ketones. ${ }^{1}$ Recently, catalytic enantioselective allylations of ketones using stannanes, ${ }^{2}$ silanes, ${ }^{3}$ boron reagents, ${ }^{4}$ allylalcohols, ${ }^{5}$ and manganese compounds ${ }^{6}$ using various chiral catalysts have been reported. However, these reactions rely on strictly anhydrous conditions or on the use of corrosive or toxic reagents. On the other hand, Barbier-type allylation using allyl halide and indium metal has shown to be an effective method for the synthesis of homoallylic alcohols, because organoindium compounds have low toxicity, and they have the ability to tolerate the reaction in water. ${ }^{7}$ Therefore, there are several papers on the enantioselective Barbier-type allylation of ketones with allyl halides using a stoichiometric amount of chiral additives and indium metal in an organic solvent. ${ }^{8}$ However, there is no report on the catalytic enantioselective Barbier-type allylation of ketones in water using indium metal and allyl halides. ${ }^{9}$ Recently, Kobayashi and co-workers first reported the catalytic enantioselective allylation of ketones in water using allylboronate and a catalytic amount of indium(0) and bis(oxazoline) catalyst to give a product with $52 \%$ ee. ${ }^{10}$ Despite the pioneering progress achieved in enantioselective reaction of

${ }^{a}$ Department of Life Science and Applied Chemistry, Graduate School of Engineering, Nagoya Institute of Technology, Gokiso, Showa-ku, Nagoya 466-8555, Japan. E-mail: snakamur@nitech.ac.jp

${ }^{b}$ Frontier Research Institute for Material Science, Nagoya Institute of Technology Gokiso, Showa-ku, Nagoya 466-8555, Japan

$\dagger$ Electronic supplementary information (ESI) available. See DOI: 10.1039/c7ra01038a allylation with ketones in water, the development of novel catalyst systems with acceptable catalytic activity and stereoselectivity still remains a major challenge. On the other hand, we recently reported the enantioselective three-component synthesis of optically active propargylamines in water ${ }^{11}$ and the enantioselective allylation of ketimines using chiral bis(imidazoline) catalysts. ${ }^{12}$ Therefore, our research interest was expanded to the catalytic enantioselective Barbier-type

Table 1 Enantioselective Barbier-type allylation of 3-bromoacetophenone $1 \mathrm{a}$ using various allyl halides $2 \mathrm{a}-\mathrm{c}$, indium, and bis(imidazoline) catalyst $4 a-d^{a}$

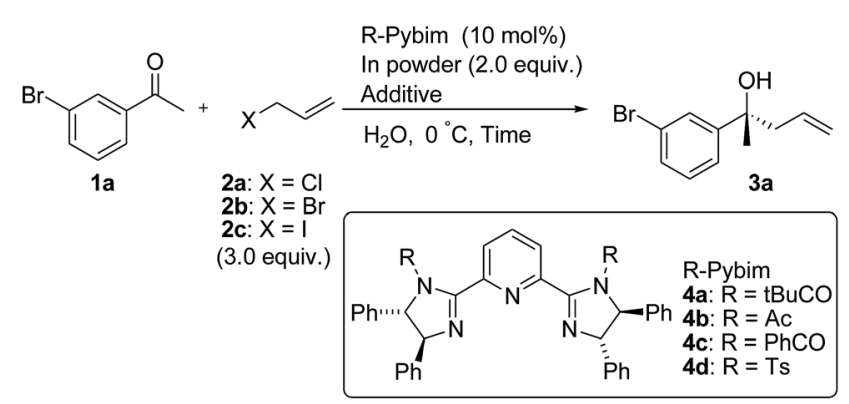

\begin{tabular}{lllllll} 
Run & X & $\mathbf{4}$ & Additive (equiv.) & Time (h) & Yield (\%) & ee (\%) \\
\hline 1 & Cl & $\mathbf{4 a}$ & - & 18 & 0 & - \\
2 & $\mathrm{Br}$ & $\mathbf{4 a}$ & - & 18 & 10 & 54 \\
3 & $\mathrm{I}$ & $\mathbf{4 a}$ & - & 18 & 80 & 76 \\
4 & $\mathrm{I}$ & $\mathbf{4 b}$ & - & 18 & 5 & 16 \\
5 & $\mathrm{I}$ & $\mathbf{4 c}$ & - & 18 & 80 & 60 \\
6 & $\mathrm{I}$ & $\mathbf{4 d}$ & - & 18 & 85 & 27 \\
$7^{b}$ & $\mathrm{I}$ & $\mathbf{4 a}$ & - & 24 & 75 & 16 \\
8 & $\mathrm{I}$ & $\mathbf{4 a}$ & $\operatorname{SDS}^{c}(0.2)$ & 18 & 99 & 30 \\
9 & $\mathrm{Br}$ & $\mathbf{4 a}$ & $\mathrm{NaI}^{(3.9)}$ & 18 & 99 & 86
\end{tabular}

${ }^{a}$ Reaction conditions: 1a $(0.10 \mathrm{mmol})$, allyl halide (3.0 equiv.), In (2.0 equiv.), and $4(10 \mathrm{~mol} \%)$ in water $(0.10 \mathrm{M})$ were used. ${ }^{b}$ In THF. ${ }^{c}$ Sodium dodecyl sulfate. 
allylation using allyl halide and indium metal using chiral bis(imidazoline) catalysts in water.

First, we examined the enantioselective Barbier-type allylation of 3-bromoacetophenone with various allyl halides (3.0 equiv.) and indium powder (2.0 equiv.) using $10 \mathrm{~mol} \%$ of chiral bis(imidazoline) ligand in water. The results are shown in Table 1.

To our delight, the reaction using allyl iodide as allyl halide afforded product $\mathbf{3 a}$ in high yield with moderate enantioselectivity, although the reaction using allyl chloride or -bromides gave product 3a in low yield (Table 1, entries 1-3). Although we investigated the effect of the substituent on imidazoline catalysts, changing the substituent on nitrogen in imidazoline catalysts from a tert-butylcarbonyl group to an acetyl, benzoyl or tosyl group could not improve the enantioselectivity of product 3a (Table 1, entries 4-6). When the reaction was carried out in THF instead of water, the enantioselectivity was significantly reduced (Table 1 , entry 7 ). In order to improve yield and enantioselectivity, we added some additives. Sodium dodecyl sulfate (SDS) was added to the reaction mixture as a surfactant, but stereoselectivity could not be improved (Table 1 , entry 8$).{ }^{13}$ On the other hand, the addition of 3.9 equiv. of $\mathrm{NaI}$ to the reaction of allyl bromide $\mathbf{2 b}$ and $\mathbf{1 a}$ improved the yield and enantioselectivity of 3a (Table 1, entry 9 vs. 2).

Having established the reaction conditions, Barbier-type allylation of various ketones with allyl bromide, indium powder and NaI using $10 \mathrm{~mol} \%$ of chiral bis(imidazoline) ligand 4a in water was examined (Table 2). The reaction of acetophenone $\mathbf{1 b}$ afforded product $\mathbf{3 b}$ in good yield with moderate enantioselectivity (Table 2, entry 2). The reaction of electrondeficient ketone $\mathbf{1 c}-\mathbf{g}$ having fluoro, chloro, or bromo groups

Table 2 Enantioselective Barbier-type allylation of various ketones $1 \mathrm{a}-\mathrm{l}$ using various allyl bromide $2 \mathrm{~b}$, indium, and bis(imidazoline) catalyst $4 a^{a}$

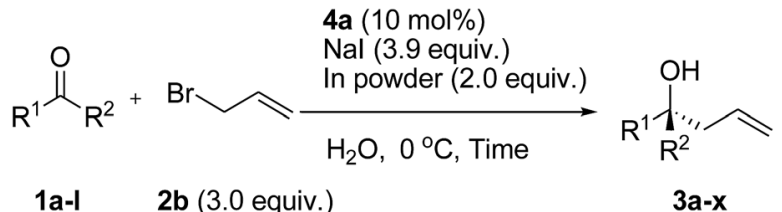

\begin{tabular}{lllllll}
\hline Entry & $\mathbf{1}$ & $\mathrm{R}^{1}$ & $\mathrm{R}^{2}$ & Time (h) & Yield (\%) & ee (\%) \\
\hline 1 & $\mathbf{1 a}$ & $3-\mathrm{BrC}_{6} \mathrm{H}_{4}$ & $\mathrm{CH}_{3}$ & 18 & 99 & 86 \\
2 & $\mathbf{1 b}$ & $\mathrm{Ph}$ & $\mathrm{CH}_{3}$ & 18 & 86 & 65 \\
3 & $\mathbf{1 c}$ & $3-\mathrm{FC}_{6} \mathrm{H}_{4}$ & $\mathrm{CH}_{3}$ & 18 & 89 & 80 \\
4 & $\mathbf{1 d}$ & $3-\mathrm{ClC}_{6} \mathrm{H}_{4}$ & $\mathrm{CH}_{3}$ & 48 & 76 & 76 \\
5 & $\mathbf{1 e}$ & $3-\mathrm{IC}_{6} \mathrm{H}_{4}$ & $\mathrm{CH}_{3}$ & 18 & 99 & 89 \\
6 & $\mathbf{1 f}$ & $2-\mathrm{BrC}_{6} \mathrm{H}_{4}$ & $\mathrm{CH}_{3}$ & 48 & 40 & 59 \\
7 & $\mathbf{1 g}$ & $4-\mathrm{BrC}_{6} \mathrm{H}_{4}$ & $\mathrm{CH}_{3}$ & 48 & 78 & 65 \\
8 & $\mathbf{1 h}$ & $3-\mathrm{MeOC}_{6} \mathrm{H}_{4}$ & $\mathrm{CH}_{3}$ & 48 & 92 & 74 \\
9 & $\mathbf{1 i}$ & $3-\mathrm{MeC}_{6} \mathrm{H}_{4}$ & $\mathrm{CH}_{3}$ & 18 & 80 & 84 \\
10 & $\mathbf{1 j}$ & $3-\mathrm{Thienyl}$ & $\mathrm{CH}_{3}$ & 24 & 90 & 55 \\
11 & $\mathbf{1 k}$ & $2-\mathrm{Naphthyl}$ & $\mathrm{CH}_{3}$ & 24 & 94 & 71 \\
12 & $\mathbf{1 l}$ & Ph & $\mathrm{CF}_{3}$ & 18 & 77 & 86
\end{tabular}

${ }^{a}$ Reaction conditions: 1 ( $\left.0.10 \mathrm{mmol}\right), 2 \mathbf{b}$ (3.0 equiv.), NaI (3.9 equiv.), In (2.0 equiv.), and $4 \mathrm{a}(10 \mathrm{~mol} \%)$ in water $(0.10 \mathrm{M})$ were used.

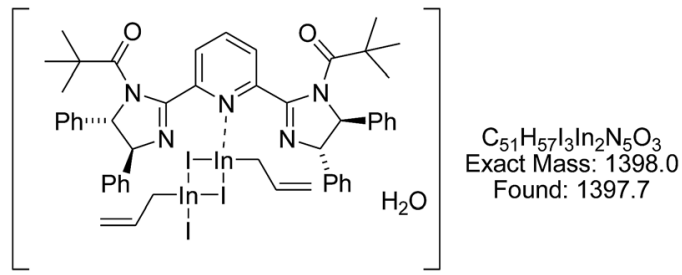

Fig. 1 ESI mass spectrum for the mixture of $4 a, 2 b, \mathrm{Nal}$ and indium in water.

in the para or meta position were tolerated in this reaction condition and gave products $\mathbf{3 c}-\mathbf{g}$ with good stereoselectivity (59-89\% ee, Table 2, entries 3-7), although the reaction of orthosubstituted ketone $1 \mathbf{f}$ gave product $3 \mathbf{f}$ in low yield and enantioselectivity (Table 2, entry 6). Ketones $\mathbf{1 h}$, i bearing an electron-donating methyl and methoxy group gave corresponding products $\mathbf{3 h}$, $\mathbf{i}$ in high yield with good enantioselectivity (Table 2, entries 8 and 9). Ketones $\mathbf{1 j}$, $\mathbf{k}$ having a naphthyl or heteroaryl group such as the thienyl group also afforded products $\mathbf{3} \mathbf{j}$, $\mathbf{k}$ in moderate yield with good enantioselectivity (Table 2, entries 10 and 11). These reaction conditions were also applicable to the reaction of trifluoromethyl ketones 11 (Table 2, entry 12). The absolute configurations of products 3a-d, $\mathbf{f}-\mathbf{l}$ were determined in comparison with the value of the specific rotation reported in the literature (see ESI $\dagger$ ). To our knowledge, these results are the first examples for the indiummediated catalytic enantioselective Barbier-type allylation of ketones in water.

In order to clarify the reaction mechanism, we conducted spectroscopic analysis. The ${ }^{1} \mathrm{H}$ NMR spectrum for the mixture of 2b, 4a, NaI, and indium powder showed a new methylene signal at $2.85 \mathrm{ppm}$ (see ESI $\dagger$ ). Chan and co-workers reported that ${ }^{1} \mathrm{H}$ NMR peaks for allylindium(III) and allylindium(I) in water were observed at $2.8 \mathrm{ppm}$ and $1.7 \mathrm{ppm}$, respectively, and that allylindium(III) make a allylindium sesquihalide species. ${ }^{\mathbf{1 4}}$ Furthermore, the ESI-mass spectroscopic analysis for the reaction mixture of $\mathbf{2 b}, \mathbf{4 a}, \mathrm{NaI}$, and indium powder showed complex A (Fig. 1: cation mode, calcd for $\mathrm{C}_{51} \mathrm{H}_{57} \mathrm{I}_{3} \mathrm{InN}_{5} \mathrm{O}_{3}$ as complex A: 1398.0 found: 1397.7). This signal implied a complex between allylindium(III) sesquihalide and $\mathbf{2 b} .^{15}$

From the above consideration and absolute stereochemistry of the products, the assumed transition state for the enantioselective
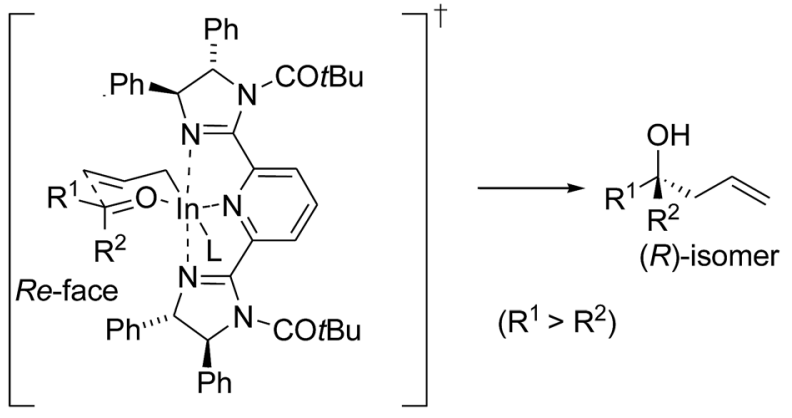

$\left(R^{1}>R^{2}\right)$

Fig. 2 Assumed transition state for the Barbier-type allylation of 1 using $4 a$. 
Barbier-type allylation of ketones using $\mathbf{4 a}$ in water is shown in Fig. 2. The allylation of ketones would proceed through a sixmembered transition state including In(III) species. ${ }^{16}$ Allylindium sesquihalide dissociates to monomeric allylindium species by coordination to bis(imidazoline), then indium(III) cation coordinates to ketones. In this transition state, indium(III) makes an octahedral structure, ${ }^{17}$ and the allyl group approaches the $R e$-face of ketones avoiding steric repulsion between the phenyl group in 4a and substituent for ketones to give ( $R$ )-homoallylic alcohols. Further studies are required to fully elucidate the mechanistic detail of the Barbier-type allylation reaction of ketones with $\mathbf{4 a}$.

In conclusion, we developed an enantioselective allylation of ketones using chiral bis(imidazoline) catalysts. To our knowledge, this is the first example of the highly enantioselective allylation of ketones using Barbier-type allylation of allyl halide and indium in water. Further experiments are in progress to study the scope of the asymmetric synthesis in water using bis(imidazoline) catalyst to other reactions.

\section{Acknowledgements}

This work was partly supported by partially supported by a Grant-in-Aid for Scientific Research from the MEXT (Japan) and Tokuyama Science Foundation.

\section{Notes and references}

1 For asymmetric allylation of ketones, see reviews: $(a)$ M. Yus, J. C. González-Gómez and F. Foubelo, Chem. Rev., 2011, 111, 7774; (b) M. Hatano and K. Ishihara, Synthesis, 2008, 1647; (c) L. F. Tietze, T. Kinzel and C. C. Brazel, Acc. Chem. Res., 2009, $42,367$.

2 (a) S. Casolari, D. D. Addario and E. Tagliavini, Org. Lett., 1999, 1, 1061; (b) K. M. Waltz, J. Gavenonis and P. J. Walsh, Angew. Chem., Int. Ed., 2002, 41, 3697; (c) H. Hanawa, S. Kii and K. Maruoka, Adv. Synth. Catal., 2001, 343, 57; (d) A. Cunningham and S. Woodward, Synlett, 2002, 43; (e) S. Kii and K. Maruoka, Chirality, 2003, 15, 68; (f) J. G. Kim, K. M. Waltz, I. F. Garcia, D. Kwiatkowski and P. J. Walsh, J. Am. Chem. Soc., 2004, 126, 12580; $(g)$ A. Cunningham, V. Mokal-Parekh, C. Wilson and S. Woodward, Org. Biomol. Chem., 2004, 2, 741; (h) J. Lu, S.-J. Ji, Y.-C. Teo and T.-P. Loh, Tetrahedron Lett., 2005, 46, 7435; (i) J. Lu, M.-L. Hong, S.-J. Ji, Y.-C. Teo and T.-P. Loh, Chem. Commun., 2005, 4217; (j) Y.-C. Teo, J.-D. Goh and T.-P. Loh, Org. Lett., 2005, 7, 2743; $(k)$ O. Prieto and S. Woodward, J. Organomet. Chem., 2006, 691, 1515; $(l)$ J. G. Kim, E. H. Camp and P. J. Walsh, Org. Lett., 2006, 8, 4413; ( $m$ ) A. J. Wooten, J. G. Kim and P. J. Walsh, Org. Lett., 2007, 9, 381; (n) X. Zhang, D. Chen, X. Liu and X. Feng, J. Org. Chem., 2007, 72, 5227; (o) J. Yadav, G. R. Stanton, X. Fan, J. R. Robinson, E. J. Schelter, P. J. Walsh and M. A. Pericas, Chem.-Eur. J., 2014, 20, 7122; (p) J. Lu and S.-J. Ji, Chin. J. Chem., 2006, 24, 1439.

3 (a) S. Yamasaki, K. Fujii, R. Wada, M. Kanai and M. Shibasaki, J. Am. Chem. Soc., 2002, 124, 6536; (b) M. Wadamoto and H. Yamamoto, J. Am. Chem. Soc., 2005,
127, 14556; (c) N. V. Hanhan, Y. C. Tang, N. T. Tran and A. K. Franz, Org. Lett., 2012, 14, 2218; (d) Z.-Y. Cao, J.-S. Jiang and J. Zhou, Org. Biomol. Chem., 2016, 14, 5500.

4 (a) R. Wada, K. Oisaki, M. Kanai and M. Shibasaki, J. Am. Chem. Soc., 2004, 126, 8910; (b) S. Lou, P. N. Moquist and S. E. Schaus, J. Am. Chem. Soc., 2006, 128, 12660; (c) D. S. Barnett, P. N. Moquist and S. E. Schaus, Angew. Chem., Int. Ed., 2009, 48, 8679; (d) S.-L. Shi, L.-W. Xu, K. Oisaki, M. Kanai and M. Shibasaki, J. Am. Chem. Soc., 2010, 132, 6638; (e) Y. Zhang, N. Li, B. Qu, S. Ma, H. Lee, N. C. Gonnella, J. Gao, W. Li, Z. Tan, J. T. Reeves, J. Wang, J. C. Lorenz, G. Li, D. C. Reeves, A. Premasiri, N. Grinberg, N. Haddad, B. Z. Lu, J. J. Song and C. H. Senanayake, Org. Lett., 2013, 15, 1710; $(f)$ R. Alam, T. Vollgraff, L. Eriksson and K. J. Szabó, J. Am. Chem. Soc., 2015, 137, 11262.

5 X.-C. Qiao, S.-F. Zhu and Q.-L. Zhou, Tetrahedron: Asymmetry, 2009, 20, 1254.

6 (a) J. J. Miller and M. S. Sigman, J. Am. Chem. Soc., 2007, 129, 2752; (b) J. J. Miller and M. S. Sigman, Angew. Chem., Int. Ed., 2008, 47, 771; (c) X.-R. Huang, C. Chen, G.-H. Lee and S.-M. Peng, Adv. Synth. Catal., 2009, 351, 3089; (d) R.-Y. Chen, A. P. Dhondge, G.-H. Lee and C. Chen, Adv. Synth. Catal., 2015, 357, 961.

7 For first indium-mediated allylation of carbonyl compounds, see: (a) S. Araki, H. Ito and Y. Butsugan, J. Org. Chem., 1988, $\mathbf{5 3}, 1831$. Reviews for indium-mediated allylation of carbonyl compounds, see; (b) U. K. Roy and S. Roy, Chem. Rev., 2010, 110, 2472; (c) Z. L. Shen, S. Y. Wang, Y. K. Chok, Y. H. Xu and T.-P. Loh, Chem. Rev., 2013, 113, 271.

8 (a) T.-P. Loh, J.-R. Zhou and X.-R. Li, Tetrahedron Lett., 1999, 40, 9333; (b) V. Thornqvist, S. Manner and T. Frejd, Tetrahedron: Asymmetry, 2006, 17, 410; (c) T. D. Haddad, L. C. Hirayama, P. Taynton and B. Singaram, Tetrahedron Lett., 2008, 49, 508; (d) T. D. Haddad, L. C. Hirayama and B. Singaram, J. Org. Chem., 2010, 75, 642. For enantioselective Barbier-type allylation of aldehydes using chiral catalysts in an organic solvent, see: $(e)$ R. P. A. Melo, J. A. Vale, G. Zeni and P. H. Menezes, Tetrahedron Lett., 2006, 47, 1829. For enantioselective Barbier-type allylation of aldehydes using stoichiometric amount of chiral additives, see: $(f)$ T.-P. Loh, J.-R. Zhou and Z. Yin, Org. Lett., 1999, 1, 1855; $(g)$ T.-P. Loh and J. R. Zhou, Tetrahedron Lett., 1999, 40, 9115; (h) L. C. Hirayama, S. Gamsey, D. Knueppel, D. Steiner, K. D. Torre and B. Singaram, Tetrahedron Lett., 2005, 46, 2315.

9 For Barbier-type allylation of ketones in water, see: $(a)$ L. A. Paquette, G. D. Bennett, M. B. Isaac and A. Chhatriwalla, J. Org. Chem., 1998, 63, 1836; (b) L. A. Paquette and P. C. Lobben, J. Org. Chem., 1998, 63, 5604; (c) C. J. Li and T. H. Chan, Tetrahedron Lett., 1991, 32, 7017; (d) T. H. Chan and Y. Yang, J. Am. Chem. Soc., 1999, 121, 3228. For Barbier-type allylation of imines in water, see: (e) W. Lu and T. H. Chan, J. Org. Chem., 2000, 65, 8589; $(f)$ X.-W. Sun, M. Liu, M.-H. Xu and G.-Q. Li, Org. Lett., 2008, 10, 1259. For catalytic enantioselective allylation of aldehyde in water, see: $(g)$ M. Ueno, A. Tanoue and S. Kobayashi, Chem. Lett., 2014, 43, 1867. For catalytic 
enantioselective Barbier-type allylation of hydrazones, see: (h) G. R. Cook, R. Kargbo and B. Maity, Org. Lett., 2005, 7, 2767; (i) R. Kargbo, Y. Takahashi, S. Bhor, G. R. Cook, G. C. Lloyd-Jones and I. R. Shepperson, J. Am. Chem. Soc., 2007, 129, 3846; (j) K. L. Tan and E. N. Jacobsen, Angew. Chem., Int. Ed., 2007, 46, 1315.

10 (a) U. Schneider, M. Ueno and S. Kobayashi, J. Am. Chem. Soc., 2008, 130, 13824. See also: (b) U. Schneider and S. Kobayashi, Angew. Chem., Int. Ed., 2007, 46, 5909; (c) U. Schneider and S. Kobayashi, Acc. Chem. Res., 2012, 45, 1331; (d) U. Schneider, I.-H. Chen and S. Kobayashi, Org. Lett., 2008, 10, 737; (e) S. Kobayashi, H. Konishi and U. Schneider, Chem. Commun., 2008, 2313.

11 M. Ohara, Y. Hara, T. Ohnuki and S. Nakamura, Chem.-Eur. J., 2014, 20, 8848.

12 (a) S. Nakamura, K. Hyodo, M. Nakamura, D. Nakane and H. Masuda, Chem.-Eur. J., 2013, 19, 7304. For related recent studies for imidazoline catalysts from our group, see: (b) S. Nakamura, K. Hyodo, Y. Nakamura, N. Shibata and T. Toru, Adv. Synth. Catal., 2008, 350, 1443; (c) S. Nakamura, M. Ohara, Y. Nakamura, N. Shibata and T. Toru, Chem.-Eur. J., 2010, 16, 2360; (d) M. Ohara, S. Nakamura and N. Shibata, Adv. Synth. Catal., 2011, 353, 3285; (e) K. Hyodo, S. Nakamura, K. Tsuji, T. Ogawa, Y. Funahashi and N. Shibata, Adv. Synth. Catal., 2011, 353, 3385; (f) K. Hyodo, S. Nakamura and N. Shibata, Angew. Chem., Int. Ed., 2012, 51, 10337; $(g)$ K. Hyodo, M. Kondo, Y. Funahashi and S. Nakamura, Chem.-Eur. J., 2013, 19, 4128; (h) S. Nakamura, K. Hyodo, M. Nakamura, D. Nakane and H. Masuda, Chem.-Eur. J., 2013, 19, 7304; (i) S. Nakamura, M. Ohara, M. Koyari, M. Hayashi, K. Hyodo, N. R. Nabisaheb and Y. Funahashi, Org. Lett., 2014, 16, 4452; (j) M. Kondo, N. Kobayashi, T. Hatanaka, Y. Funahashi and S. Nakamura, Chem.-Eur. J., 2015, 21, 9066; (k) M. Kondo, T. Nishi, T. Hatanaka, Y. Funahashi and S. Nakamura, Angew. Chem., Int. Ed., 2015, 54, 8198; (l) S. Nakamura, J. Synth. Org. Chem., Jpn., 2015, 73, 1062; (m) S. Nakamura, N. Matsuda and M. Ohara, Chem.-Eur. J., 2016, 22, 9478.

13 We also examined reactions with various additives, such as ammonium bromide, cetyltrimethylammonium bromide and 18-crown-6, however the yield and enantioselectivity of the product was low (see ESI $\dagger$ ).

14 T. H. Chan and Y. Yang, J. Am. Chem. Soc., 1999, 121, 3228. 15 We also examined the enantioselective allylation reaction using various ratios of allyl bromide and indium. The best result was obtained in the reaction using allyl bromide and indium in a $3: 2$ ratio (see ESI $\dagger$ ). This result supports the formation of indium(III) sesquihalide species.

16 (a) J. H. Dam, P. Fristrup and R. Madsen, J. Org. Chem., 2008, 73, 3228; (b) I. A. Olson, A. M. Sessler, J. L. Connell, E. Giordano, Y. Y. Baez Sosa, S. W. Zavaleta and W. J. Bowyer, J. Phys. Chem. A, 2009, 113, 2801; (c) K. Koszinowski, J. Am. Chem. Soc., 2010, 132, 6032. See also ref. $7 b$ and $c$.

17 (a) M. Yasuda, M. Haga and A. Baba, Organometallics, 2009, 28, 1998; (b) M. Yasuda, K. Kiyokawa, K. Osaki and A. Baba, Organometallics, 2009, 28, 132. 